International Journal of Advanced Studies in Humanities and Social Science (IJASHSS)

Available online at http://www.ijashss.com

Volume 8, Issue 3 (2019) pp. 223-240

Original Article

\title{
A Comprehensive Literature Review in Competitive Advantages of Businesses
}

\author{
Manijeh Gareche ${ }^{1}$, Seyed Mahmoud Hosseini' ${ }^{1}$, Masoud Taheri² \\ ${ }^{1}$ Faculty Member of Management and Accounting, Shahid Beheshti University, Tehran, Iran \\ ${ }^{2}$ Faculty of Management and Accounting, Shahid Beheshti University, Tehran, Iran
}

Received: 24 October 2018, Revised: 05 December 2018, Accepted: 20 December 2018

\begin{abstract}
The previous studies on the field of competitive advantages of businesses were reviewed. Competitive advantage refers to a set of factors or capabilities that enable the company to demonstrate better performance comparing to the competitors. Totally 59 articles in eight different fields, including strategic management, strategic management of marketing, marketing management, information technology, knowledge management, resources-based theory, entrepreneurship, and human resource management, were reviewed. The results showed that among several available methods, a majority of businesses employ Porter's triple strategies, namely differentiation, centralization, and cost leadership, to gain competitive advantages. Among the triple strategies, the strategy of differentiation has drawn the highest attention and simultaneous utilization of the three strategies is a rare case.
\end{abstract}

Keywords: Competitive Advantage, Resource-Based Theory, Differentiation Strategy, Centralization Strategy, Cost Leadership Strategy.

\section{Introduction}

Business world nowadays is featured with intensive competition with national and foreign rivals. As a result, businesses that fail to deal with the changes are most likely to lose considerable share of their market and profit. Finding a suitable place in the intensive competitive environment is the key to long-term profitability and survival of a business; a goal which is only attainable through creating and keeping competitive advantages. The term "competitive advantage" refers to a "set of capabilities that permanently enable the business to demonstrate better performance in comparison to its competitors" (Bobillo et al.,
2010). According to Porter's reasoning, there are three ways to achieve competitive advantage: cost leadership, centralization and creating differentiation of product. He argued that businesses should think about how they enter a market and then create and keep a proper competitive position for themselves. (Porter, 1980)

There are two general viewpoints to elaborate on stable competitive position in an organization. The first viewpoint is developed on the industrial organization theory introduced by Michel Porter in the 1980s as a prevailing viewpoint, in which attaining competitive advantage is caused by 
environmental opportunities. Analytical tools used in this viewpoint include analysis of organization value chain, analysis of competitive forces, general strategies (cost leadership, differentiation, and centralization), competitiveness, clusters, competitive advantages of nations, and so on. The second viewpoint is the resource-based theory, in which it is argued that every business creates its own competencies, and capabilities which eventuate in competitive advantage. In fact, permanent competitive advantage and weakness and strength features of the business are mainly under consideration. (Moreno et al., 2012).

\section{Methodology and Findings}

Articles with the term "competitive advantage" in their title or keywords, which have been indexed in Science Direct and Emerald were adopted for analysis. It is noteworthy that to have more accurate survey only articles published between 1980 and 2013 were adopted.

Sheng and Chang (2012) surveyed the effect of information and communication technology (ICT) on transfer of knowledge and on achieving innovation in competitive advantages in medical sector of Taiwan. Obstacles ahead of transfer of knowledge were problems in an organization and ambiguity of the knowledge (i.e. ambiguity of cause and effect relations of the knowledge). The results of data analysis showed that capability of the organization in ICT field had positive and significant effect on transfer of knowledge and that the transfer improved the development of attaining innovation regarding competitive advantage in the organization.

In their study, Lew and Sinkovics (2013) examined the effect of strategic unity at international level and its effect on competitive advantage. They concluded that high-technology industries enjoy strategic alliance as the source of product development, wining international market share, and developing competitive advantages.

Lim et al. (2012) reported that the stronger the IT ward managers regarding the structural power in organizational hierarchy, the stronger the IT role in the organization and the more the competitive advantages for the organization.

Hazen and Byrd (2012) found that new information technologies such as electronic data interchange (EDI) and FRID technology have positive effect on attaining competitive advantages and expansion of innovation. They maintained that these technologies may bring differentiating features for the business.

Moreno et al. (2012) demonstrated that environmental human resources (HR) management enhances competitive advantages of the companies. Indeed, such businesses employ researchers to create competitive advantages.

Rugraff (2012) conducted a study in car industry of Czech and found that two main factors of creating competitive advantages in the industry was forward-looking and backward-looking merger or the suppliers in the industry (participation in and sharing resources of customers and suppliers).

Kim et al. (2012) stated that recruitment of trained and skilled staff improves competitive advantage of the organization and differentiation among other industries.

$\mathrm{Li}$ and Zhou (2010) studied the effective factors on attaining competitive advantages in 179 foreign countries in China with the presumption that these companies have accepted market tendency and integrity of management. They found that market trend and management integrity could create competitive advantage through attenuating costs, differentiation, and diversity in the market.

Oh and Rhee (2010) argued that Korean car industry has achieved competitive 
advantages in the world industry through combining capabilities of suppliers and merging (cost leadership strategy).

Feng et al. (2010) conducted a study in China between 2008 and 2009 and concluded that customer and suppliers' participation throughout the process of attaining competitive advantages (cost leadership strategy) improves competitive advantages of the industry.

Bobillo et al. (2010) studied 1500 manufacturing firms in Germany, France, the UK, Spain, and Denmark and maintained that organizational factors (e.g. capital markets, financial liaison, and skilled work force) differentiation strategies approaches- have positive effect on attaining competitive advantages.

Focusing on competitive advantages of food industries, Massa and Testa (2009) found through their surveys on found that knowledge management process is positively effective on attaining competitive advantages in the industry and enables utilization of differentiation, centralization, and cost leadership strategies.

Tan (2009) held that relation between the staff and the company is strengthened through creating common values in a company, which eventuates in competitive advantages.

Ling and Chen (2008) launched a study on a model for attaining competitive advantages and reported that sharing knowledge and forward-looking/backward-looking mergers (with customers, suppliers, and distributers) - cost leadership strategy- improves competitive advantages in long-run.

Tan (2009) maintained that mutual relation between the staff and the company can improve through creation of common values in an organization; which is the source of competitive value.

Lin and Chen (2008) studied a model to gain competitive advantages and concluded that sharing knowledge and forward- looking/backward-looking mergers (with customers, suppliers, and distributors) (cost leadership strategy) could lead to development of long-term competitive advantage.

Awuah and Gebrekidan (2008) addressed the development of competitive advantages that recognition of key elements in competitive networks and establishment long-term relation with the elements (cost leadership strategy) creates competitive advantages for firms.

Koh et al. (2007) studied small and medium size businesses in the UK and found that electronic business and the Internet (differentiation and centralization strategy) were positively and significantly effective in competitive advantages of firms.

In a survey of 56 Thai firms in semiconductor industry, Liao and Chien $\mathrm{Hu}$ (2007) suggested that through affecting central qualifications in an organization, transfer of knowledge eventuates in competitive advantage in the organization, while uncertainties in external environment negatively influences transfer of knowledge and acquisition of competitive advantages.

Swink and Song (2007) maintained that the development of new products (centralization strategy) creates and increases competitive advantages of businesses.

In their study, Toppinen et al. (2007) showed that key factors of success, organizational capabilities, and organizational resources (differentiation and centralization strategy) could lead to acquisition of competitive advantages in businesses.

Silvi and Guganesan (2006) found that cost knowledge management (strategic cost management viewpoint) added to competitive advantages (through utilization of cost leadership strategy) in four Italian companies. 
In their survey on the effects of electronic businesses on several real estate agencies in China, Hinton and Tao (2006) showed that electronic businesses were positively and significantly effective in performance and competitive advantages of businesses and resulted in differentiation from the rivals.

Castro et al. (2006) maintained that organizational capital (culture, structure, and learning) differentiate the firms that possess such capitals from their competitors and create competitive advantages.

Khandekarand Sharma (2005) polled 300 employees and managers in 9 Chinese companies in international market and found that ability of human resources poses positive and significant effect on competitive advantage.

Chuang (2004) found that implementation of knowledge management improved competitive advantage of a business.

Hunt and Amett (2004) maintained that utilization of competitive-centered viewpoint and marketsectoring (centralization strategy) could bring competitive advantages to businesses.

Based on the results of their study, Awaz (2004) concluded that utilization of informal networks could increase competitive advantages through backward/forwardlooking merger with partners (cost leadership strategy).

Adams and Lamont (2003) recommended that knowledge management, organizational resources, innovation and differentiation of products, and organization learning is most likely to improve competitive advantages of businesses.

Rigamampianina et al. (2003) maintained that Porter general strategies (differentiation, centralization, cost leadership strategy) helps to result in competitive advantages for organization.

Based on their results of data analyses, Davis et al. (2003) concluded that utilization of IT based strategies attenuated costs of company, differentiated the products, and created innovation which could bring considerable competitive advantages to the organization.

In an article, Erikson (2002) found that entrepreneurship capital consisting of entrepreneurship capabilities and commitment was positively and significantly effective in competitive advantage.

Relying on their inquiry, Longeneker and Ariss (2002) concluded that learning and development indices improve skills management and performance of the organization, which may result in competitive advantage.

Though surveying the available models regarding competitive advantages, Walters et al. (2002) argued that tangible and intangible values and value of materials and equipment, services, salary, wage, investment costs performance were effective in competitive advantages.

On the basis of their three-dimension model of competitive advantage, Fudson and Radnor (2002) reported that organization, people, and practices are mutually interactive and positively affect competitive advantages through specific measures.

Based on a proposed model, Kaleka (2002) maintained that organizational resources and capabilities and utilization of Porter's triple strategies improve competitive advantages in organizations.

Likewise, Fahy (2002) suggested that resource-based viewpoints can exert positive impact competitive advantages of an organization.

In their study on information systems and their effects on competitive advantages, Zhang and Lado (2001) found that information systems improve databased/transfer-based/information-based

merits and eventuate in competitive advantages.

In their study on medical treatment and tourism, Preble et al. (2000) concluded that 
strategic unions (cost leadership strategy) lead to sharing resources between two companies, innovation in new products and entering into new markets, as well as easy access to new markets and acquisition of competitive advantages.

Keams and Lederer (2000) argued that strategic harmony between information systems and business plans have positive and significant effect on organizational performance and competitive advantage.

In one of their studies Reed et al. (2000) reasoned that through development of products with lower quality (achieving cost leadership strategy), variety of products to meet different tastes (differentiation strategy) and the way it deals with organizational complexities, comprehensive quality management leads the organizational toward competitive advantages.

In their model of competitive advantage, Mazzarol and Souter (1999) demonstrated that strategies to enter the market (cost leadership strategy), marketing strategies, industries structure and external market structure create competitive advantages for businesses in higher education field.

Morgan and Hung (1999) surveyed the effect of marketing strategies and communications using resource-centered viewpoint. Organizational resources under consideration in the study and their influence on competitive advantage through marketing relations are listed along with some examples in the table below.

In their survey, Morgan and Hunt (1999) found that organizational based marketing relation was positively and significantly effective in organizational resources.

in their study on Australian manufacturing industries, Yamin et al. (1999) showed that Porter's general strategies (cost leadership, differentiation, and centralization strategy) positively affected competitive advantages and performance of the company.
Olson et al. (1998) maintained that organizations' strategic design and marketing leave positive and significant effect on competitive advantages of organizations provided that we take into account key merits of the organization, strategy centralization level (centralization on business, sector, or line of product), pricing limitations, resource and production merits, preferences of consumer on product design along with issues such as market development and variety of mergers.

Following several supporters of resourcebased approaches for realization of competitive advantages, Piercy et al. (1998) concluded that organizational resources and skills result in competitive advantages.

Porter (1997) argued that structural features of an organization such as entry of new investors, threats of being replaced, customers' negotiation power, suppliers' negotiation power, and competition among rivals all play effective roles in realization of competitive advantages of a firm.

Whitehill (1997) argued that knowledgebased strategies, which are intangible and hardly achievable for the competitors, may be a source of competitive advantage for the company.

In their study, Whiteley and Hessan (1996) maintained that implementation of customer-oriented approach leads the organization toward competitive advantage through differentiation and centralization strategies.

Slater (1996) enlisted the methods to achieve competitive advantage including quality of services and products, provision of proper services throughout the process of introduction of products/purchase/after sale services, lower cost of production and services comparing with other competitors, pace of introduction of new and innovative products, innovation in provision of products and services, and promotion of learning culture throughout the organization (cost 
leadership, differentiation, and centralization strategies).

In a study on Japanese companies, Krause (1995) maintained that vertical merger strategy (upward and downward) (cost leadership strategy) has positive effect on competitive advantages of organization.

Long and Koch (1995) and Juttner and Wehrli (1994) portrayed in their model that central advantages and strategic processes (cost leadership, differentiation, and centralization strategies) and organizational sources lead to competitive advantages.
Turner (1991) showed that marketing information is positively and significantly effective in the three strategies of cost leadership, differentiation, and centralization.

In his well-known book, Porter (1980) named three competitive strategies for realization of competitive advantages in organization including cost leadership strategy, differentiation, and centralization; which are the bases of the studies named above. (Porter, 1987).

Table 1 lists the summary of researchers' viewpoints based on main and secondary factors pertinent to competitive advantages.

Table 1. Summary of literature review based on main and secondary factors in competitive advantages

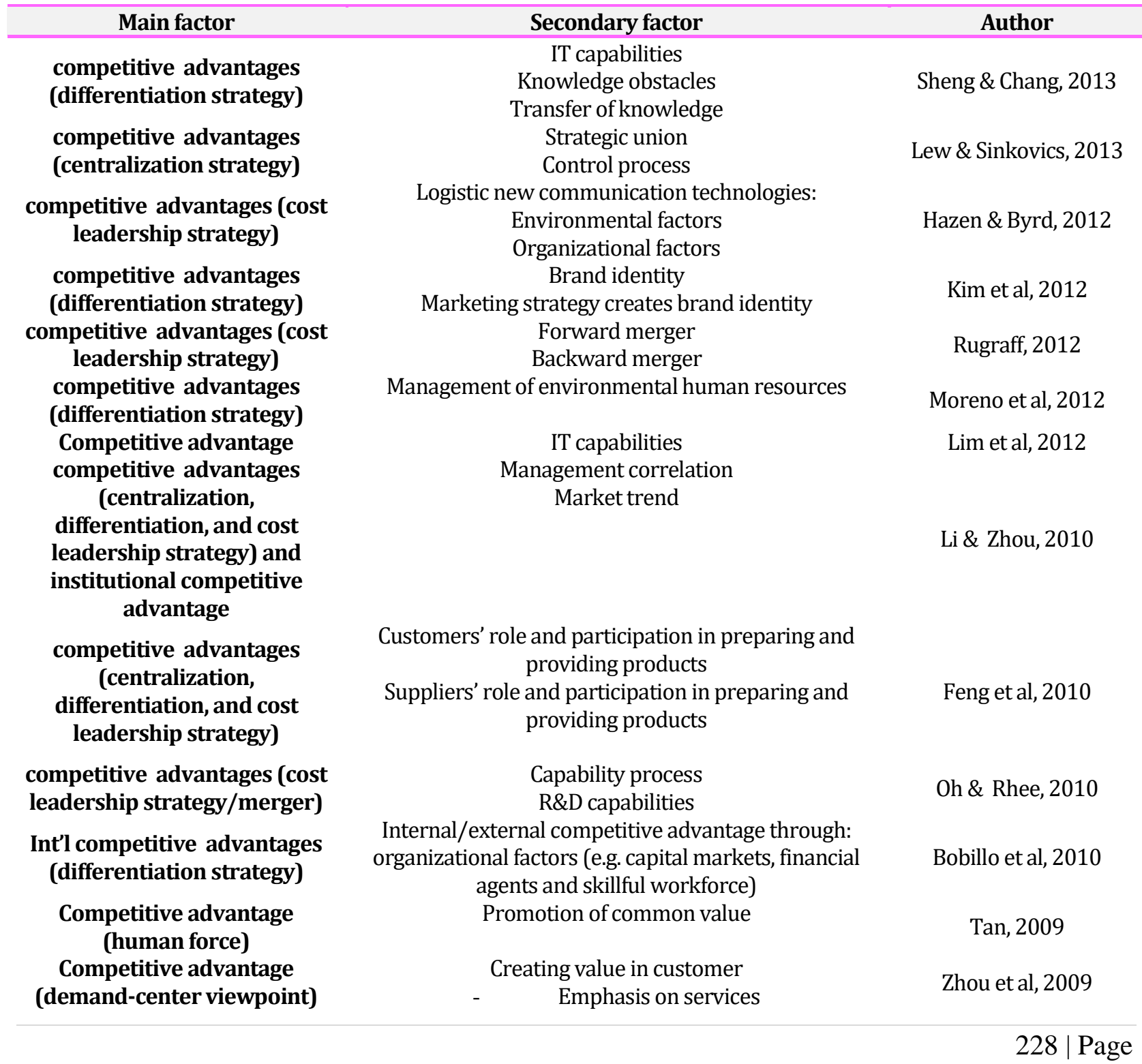


(competitive advantage through differentiation in market and innovation; differentiation strategy)

\section{Competitive advantage}

Competitive advantage

competitive advantages (differentiation and cost leadership strategy)

competitive advantages (cost leadership strategy)

competitive advantages (centralization strategy)

Competitive advantage

Competitive advantage (resource-centered approach)

competitive advantages (centralization, differentiation, and cost leadership strategy) competitive advantages (cost leadership strategy)

Competitive advantage (resource-centered approach)

competitive advantages (differentiation and cost leadership strategy)

competitive advantages (differentiation strategy)

Competitive advantage

competitive advantages (centralization strategy)

\section{Emphasis on prices \\ - $\quad$ Market trend \\ - $\quad$ Customer trend \\ - $\quad$ Competition trend}

Knowledge management

Acquisition or development of knowledge

Knowledge storage

Massa \&Testa, 2009

Knowledge transfer/ sharing

Utilization of knowledge

Cost leadership strategy

Differentiation of strategy

Centralization strategy

Condition of competitive environment

Organizational merger

- $\quad$ Internal merger

Knowledge sharing

Knowledge sharing

Innovation capacity in organization

Identification of key elements in network and establishment of long-term communication through

forward/backward communication

Production-marketing mixture through development of new products

Environmental uncertainty

Knowledge transfer

Key factors of success of industry

Competition strategy

Organizational resource

Organization capabilities

Utilization of the Internet and new information technologies

cost knowledge management

Organizational capitals:

- Organizational culture

- $\quad$ Organizational structure

- $\quad$ Organizational learning

Electronic business:

- $\quad$ Electronic learning

- $\quad$ Customer relation management

- $\quad$ Web-based marketing

- $\quad$ Electronic services

- $\quad$ Electronic supplies

- Office automation

Human resource abilities

Industrial texture

Environmental uncertainties Information intensity

Necessity of IT

Entrepreneurship intensity

Learning capability of market concentration Marketing capability
Koh et al, 2007

Silvi \& Cuganesan, 2006

Awuah\&Gebrekidan, 2008

Swink\& Song, 2007

Liao \&Chien Hu, 2007

Toppinen et al, 2007

Castro et al, 2006

Hinton \& Tao, 2006

Khandekar \& Sharma, 2005

Kearns \& Lederer, 2004

Weerawardena \&

O'Cass, 2004 


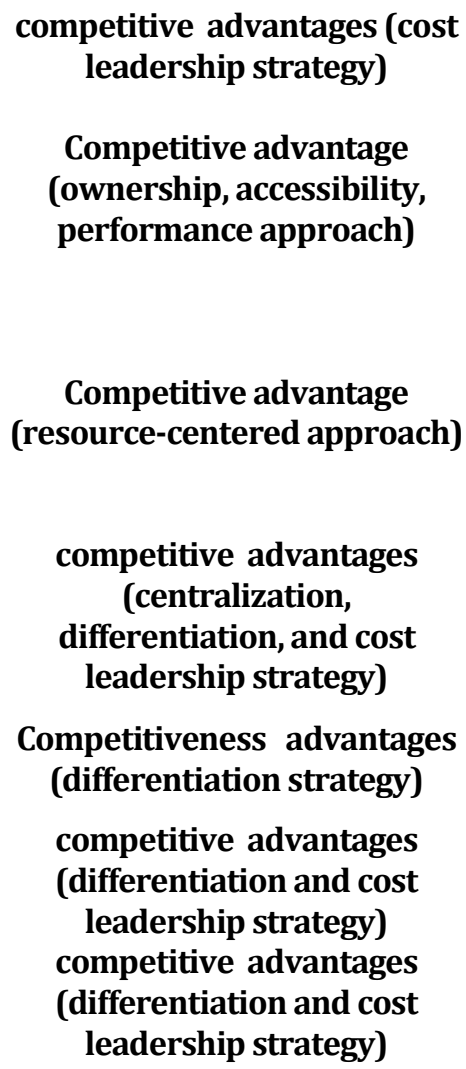

Competitive advantage (resource-centered approach)

competitive advantages (centralization, differentiation, and cost leadership strategy)

Competitiveness advantages (differentiation strategy)

competitive advantages (differentiation and cost leadership strategy) competitive advantages (differentiation and cost leadership strategy)

competitive advantages (differentiation strategy)

Competitive advantage (resource-centered approach)

competitive advantages (centralization, differentiation, and cost leadership strategy)

Triple aspects of competitive advantage

Competitive advantage (resource-centered approach)

Competitive advantage

Competitive advantage

competitive advantages (differentiation and cost leadership strategy)
Knowledge capability merger through informal communication networks

Awaz, 2004

Acceptance as colleague (cost leadership/merger strategy)

Type of competition (centralization)

Ma, 2004

Innovation and creativity (differentiation strategy)

Collaboration (merger)

Knowledge management:

Social science management including: human

resources, innovation supporting organizational culture, structural resources

Chuang, 2004

Technical/technological knowledge

management including: IT, hardware and software

Competition centered viewpoint: utilization of competitive resources (cost leadership and differentiation)

Market sectoring (concentration)

Investment toward improvement of obstacles of

copying; emphasis on variety and differentiation of products

Knowledge management systems efficiency

- $\quad$ Resource-based organizational learning

Financial resources of company IT based strategy

Hunt \& Arnett, 2004

Rigamampianina et al, 2003

Adams \& Lamont, 2003

Davis et al, 2003

Entrepreneurship capital:

Entrepreneurship capabilities including:

perceived flexibility, entrepreneurship creativity, entrepreneurship merits, organizational capabilities, self-efficiency to reach resources, perceived behavioral control, entrepreneurship commitment

Sources of national competitive advantages:

Fundamental resources Advanced resources

Competitive advantages sources of company:

Tangible and intangible assets

Human resources capabilities

Resources of organization

Organization capabilities

Individuals

Organization

Fudson \& Radnor, 2002

Scheduled organizational practices

Value of company

Value added

Skills management improvement and organizational

performance management

Information systems effects

Information data-based merits

Transfer-based merits

Information-output merits

Strategic unions
Kaleka, 2002

Erikson, 2002

Fahy, 2002

Walters et al, 2002

Longenecke \& Ariss, 2002

Zhang \& Lado, 2001

Preble et al, 2000 


\section{Competitive advantage (resource-centered approach) \\ competitive advantages (centralization, differentiation, and cost leadership strategy) \\ Competitive advantage (resource-centered approach) \\ Int'l competitive advantages (centralization, differentiation, and cost leadership strategy)}

\section{Competitive advantage}

Competitive advantage (resource-centered approach) including product competitive advantage (centralization strategy)

Service competitive advantage (differentiation strategy) Cost competitive advantage (cost leadership strategy)

Competitive advantage (technological advantages of firm)

Competitive advantage (resource-centered approach)

competitive advantages (centralization, differentiation, and cost leadership strategy)

Competitive advantage (industry/structure-centered organization approach)
Coordination of information systems design and business plan

Coordination of business and information system design

Comprehensive quality management

Kearns \& Lederer, 2000

Reed et al, 2000

Marketing strategies and communications (cost leadership strategy and differentiation strategy)

Morgan \& Hunt, 1999

External market and industry structure: Internal/external marketing strategy

External market entry strategy Different merits

Copying obstacles

Cost leadership strategy

- Differentiation strategy

- Centralization strategy

Organizational resources:

$\begin{array}{cc}- & \text { Physical } \\ - & \text { Financial } \\ & \text { Exporting experience } \\ \text { Human force skills } \\ \text { Information skills }\end{array}$

Customer communication skill

Development of product (centralization strategy)

- $\quad$ Supply chain

management technical knowledge

Ghingold \& Johnson, 1998

Hill \& Jones, 1998

Effective factors in marketing strategy design and organization:

Organization key merits

Strategy centralization level (concentration on company, sector, or line of product)

Connection between image of company and targets of company

Taking into account the factors in production (direct/indirect factors such as workers, suppliers, managers, etc.)

Taking into account limitations of pricing, resource merits and production

Taking into account preferences of consumers during product design

Taking into account issues such as market development and different merger (upward/downward)

Entry of new investors

Purchasing negotiation power

Suppliers negotiation power

Competition among new rivals
Olson et al, 1998

Porter, 1997 


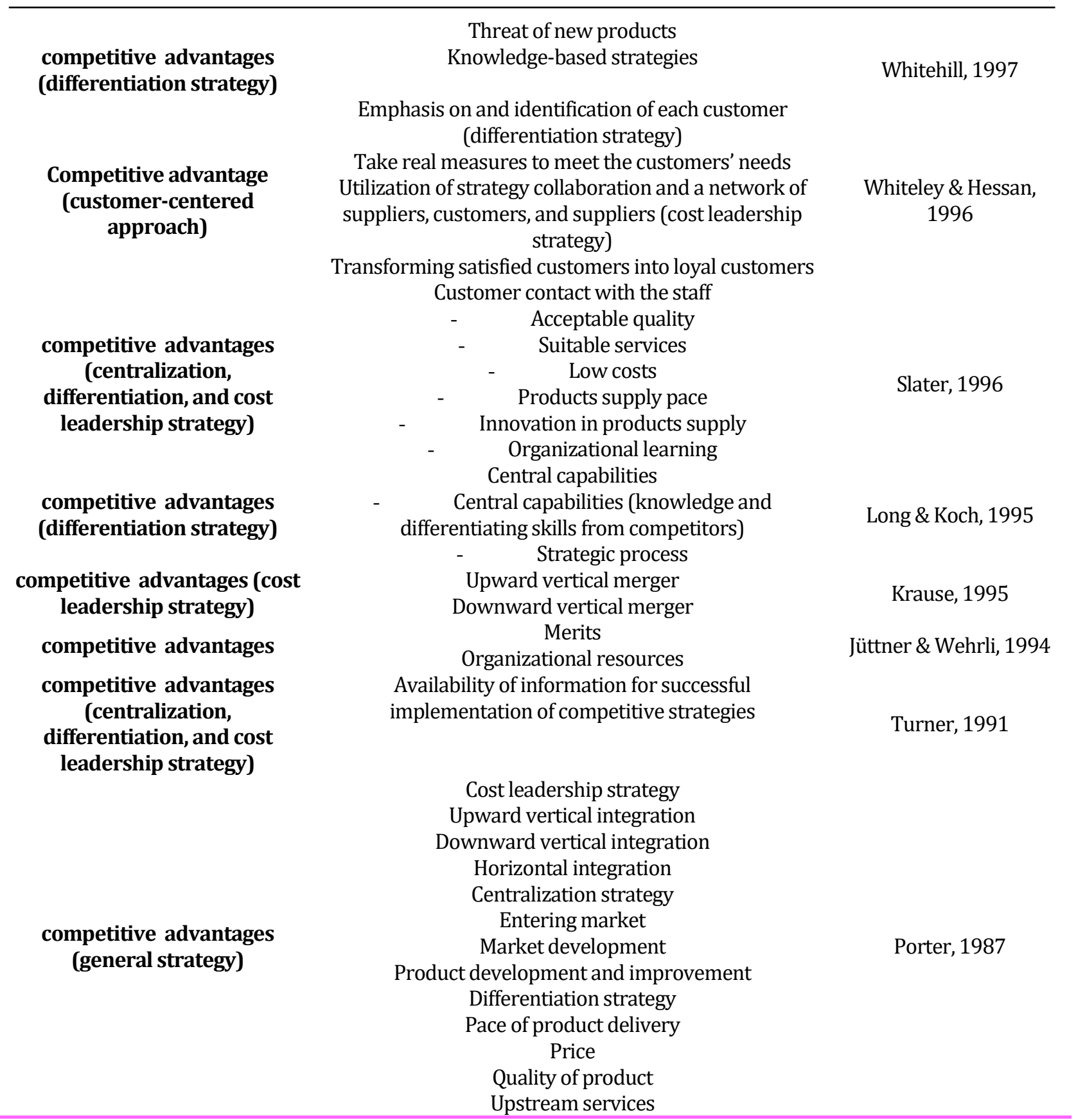

The literature review results imply that there are 8 distinct groups in the field of competitive management including strategic management, knowledge management, resource-based theory, entrepreneurship, IT, marketing management, marketing strategic management, and HR management. Diagram1 pictures frequency of the studies on each one of these eight groups. These studies can be classified based on the specific variables that each study has dealt with. For instance, some works have focused on IT and some others on HR. Table 2 lists the studies based on their field of study.

As illustrated in the figure above, two groups of strategic management and resource-based theory have the highest frequencies. The most dominant result of strategic management is the consistency between competitive advantage of a 
company and its capabilities. That is, the main task of the management is to exert harmony between merits of the organization (skills and internal resources) and the opportunities and risks exerted by environmental changes. On the other hand, resource-based theory is one of the main theories introduced in strategic management literature concerning competitive advantage. The theories in contrary with industrial organizational theory in which competitive advantage is the outcome of external factors. It actually takes internal resources of the organization as the source of competitive advantages and emphasizes the fact that organizations may achieve competitive advantages based on inconsistency of the resources they posse; what several studies have expressed interest in. The majority of the studies have focused on Porter's triple competitive strategies; while some have focused on one, two, or all three strategies. One may conclude from these studies that Porter's model of competitive strategies, thanks to coordinating aspects for exports of oil products, suffices for measuring and achieving competitive advantages. Taking into account aspects of distinction - cost leadership, and centralization strategies (Porter's general strategies) - the present study also reviews the studies that have analyzed the aspects (Table 3 and diagram 3 ).

Table 2. Competitive advantages studies based on field of study

\begin{tabular}{|c|c|c|}
\hline No. & Reference & Field of study \\
\hline 1 & Preble et al, 2000 & Strategic management \\
\hline 2 & Chuang, 2004 & $\begin{array}{l}\text { Resource-based knowledge } \\
\text { management }\end{array}$ \\
\hline 3 & Erikson, 2002 & Entrepreneurship \\
\hline 4 & Davis, et al, 2003 & IT \\
\hline 5 & Yamin et al, 1999 & Strategic management \\
\hline 6 & Massa \&Testa, 2009 & IT \\
\hline 7 & Rugraff, 2012 & Strategic management \\
\hline 8 & Salavou\&Halikias, 2009 & Strategic management \\
\hline 9 & Awuah\&Gebrekidan, 2008 & Strategic management \\
\hline 10 & Silvi\&Cuganesan, 2006 & Knowledge management \\
\hline 11 & Castro et al, 2006 & Resource based \\
\hline 12 & Khandekar\& Sharma, 2005 & Resource based \\
\hline 13 & Morgan \& Hunt, 1999 & Resource-based strategic management \\
\hline 14 & Olson et al, 1998 & Strategic management \\
\hline 15 & Whitehill, 1997 & Knowledge-based strategic management \\
\hline 16 & Krause, 1995 & Strategic management \\
\hline 17 & Zhang \&Lado, 2001 & IT \\
\hline 18 & Whiteley\&Hessan, 1996 & Strategic management \\
\hline 19 & Slater, 1996 & Marketing management \\
\hline 20 & Hunt \& Arnett, 2004 & Marketing management \\
\hline 21 & Kim et al, 2012 & Marketing strategic management \\
\hline 22 & Moreno et al, 2012 & HR management \\
\hline 23 & Koh et al, 2007 & IT \\
\hline 24 & Hinton \& Tao, 2006 & IT \\
\hline 25 & Khandekar\& Sharma, 2005 & HR management \\
\hline 26 & Bobillo et al, 2010 & Marketing management \\
\hline 27 & Lim et al, 2012 & IT \\
\hline 28 & Kearns \&Lederer, 2004 & IT \\
\hline 29 & Swink\& Song, 2007 & Marketing management \\
\hline 30 & Kearns \&Lederer, 2000 & IT \\
\hline 31 & Liao \&Chien Hu, 2007 & Knowledge management \\
\hline 32 & Fahy, 2002 & Resource based \\
\hline 33 & Reed et al, 2000 & Marketing management \\
\hline 34 & Tan, 2009 & HR management \\
\hline 35 & Li \& Zhou, 2010 & Marketing management \\
\hline
\end{tabular}




\begin{tabular}{|c|c|c|}
\hline 36 & Lew \&Sinkovics, 2013 & Marketing strategic management \\
\hline 37 & Weerawardena\&O'Cass, 2004 & Entrepreneurship \\
\hline 38 & Piercy et al, 1998 & Resource based \\
\hline 39 & Zhou et al, 2009 & Marketing management \\
\hline 40 & Kaleka, 2002 & $\begin{array}{l}\text { Marketing management } \\
\text { Resource based }\end{array}$ \\
\hline 41 & Long \& Koch, 1995 & Resource based \\
\hline 42 & Feng et al, 2010 & Strategic management \\
\hline 43 & Mazzarol\&Soutar, 1999 & Marketing strategic management \\
\hline 44 & Fudson\& Radnor, 2002 & Resource based \\
\hline 45 & Turner, 1991 & $\begin{array}{c}\text { IT } \\
\text { Marketing strategic management }\end{array}$ \\
\hline 46 & Jüttner\&Wehrli, 1994 & Resource based \\
\hline 47 & Ghingold\& Johnson, 1998 & Knowledge management \\
\hline 48 & Rigamampianina et al, 2003 & Marketing strategic management \\
\hline 49 & Walters et al, 2002 & Marketing strategic management \\
\hline 50 & Walters et al, 2002 & HR management \\
\hline 51 & Awaz, 2004 & Strategic management \\
\hline 52 & $\mathrm{Ma}, 2004$ & Marketing strategic management \\
\hline 53 & Sheng \& Chang, 2013 & Knowledge management \\
\hline 54 & Hazen \& Byrd, 2012 & IT \\
\hline 55 & Oh \& Rhee, 2010 & $\begin{array}{l}\text { Strategic management } \\
\text { Resource based }\end{array}$ \\
\hline 56 & Lin \& Chen, 2008 & $\begin{array}{l}\text { Strategic management } \\
\text { Knowledge management }\end{array}$ \\
\hline 57 & Toppinen et al, 2007 & $\begin{array}{l}\text { Strategic management } \\
\text { Resource based }\end{array}$ \\
\hline 57 & Hill \& Jones, 1998 & Resource based \\
\hline 58 & Porter, 1997 & Marketing strategic management \\
\hline 59 & porter, 1987 & Marketing strategic management \\
\hline
\end{tabular}

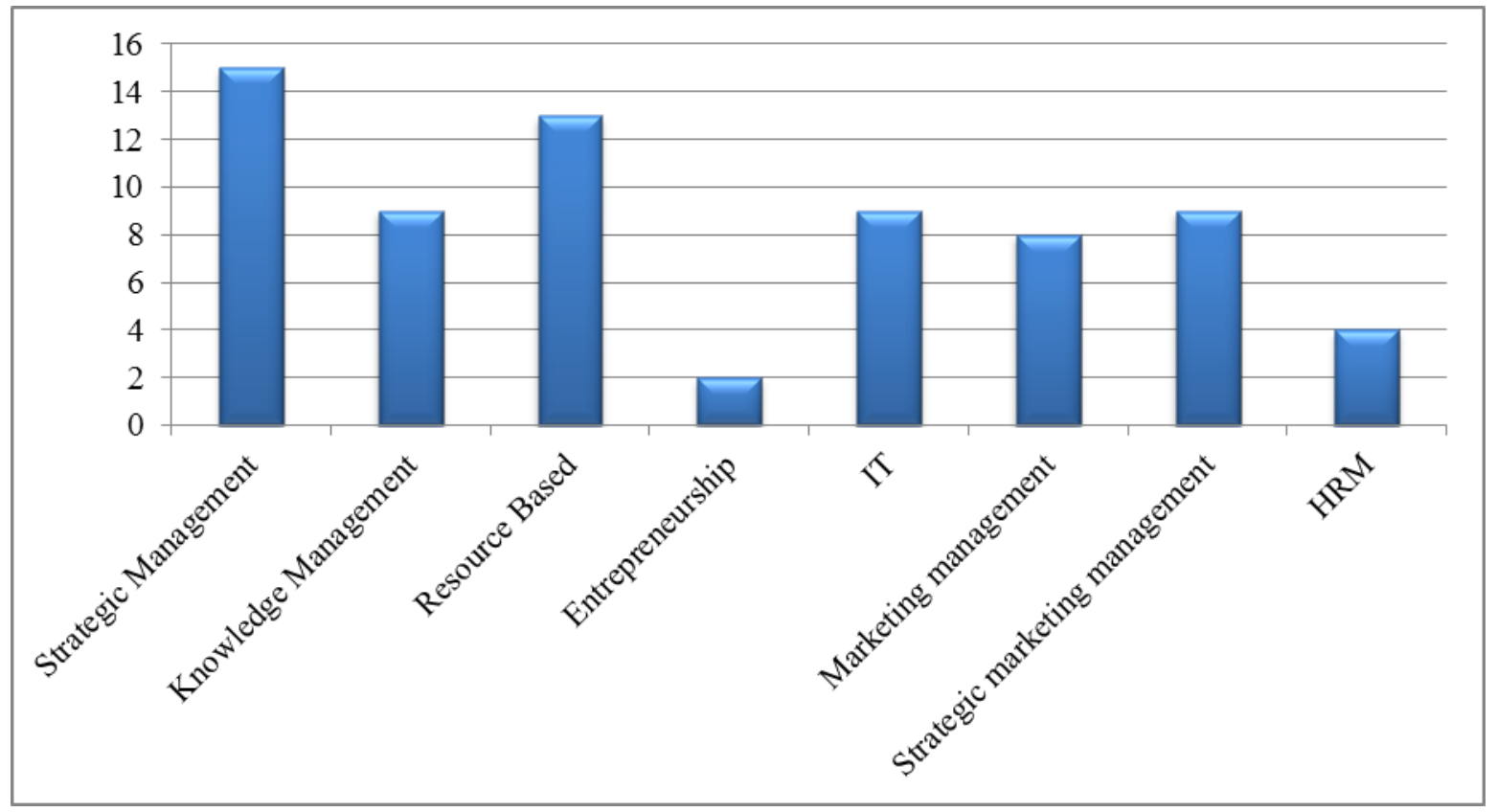

Figure 1. Fields of study on competitive advantages

As pictured in Figure 2, there are few studies dealing with the three general strategies (cost leadership, differentiation, and centralization) in one work The distinguishing feature of the present study is that these three strategies have been 
surveyed simultaneously. The reason for employing Porter's general strategies in conceptual model for surveying competitive advantages is further explained in the conclusion.

Table 3. Aspects under study by previous studies

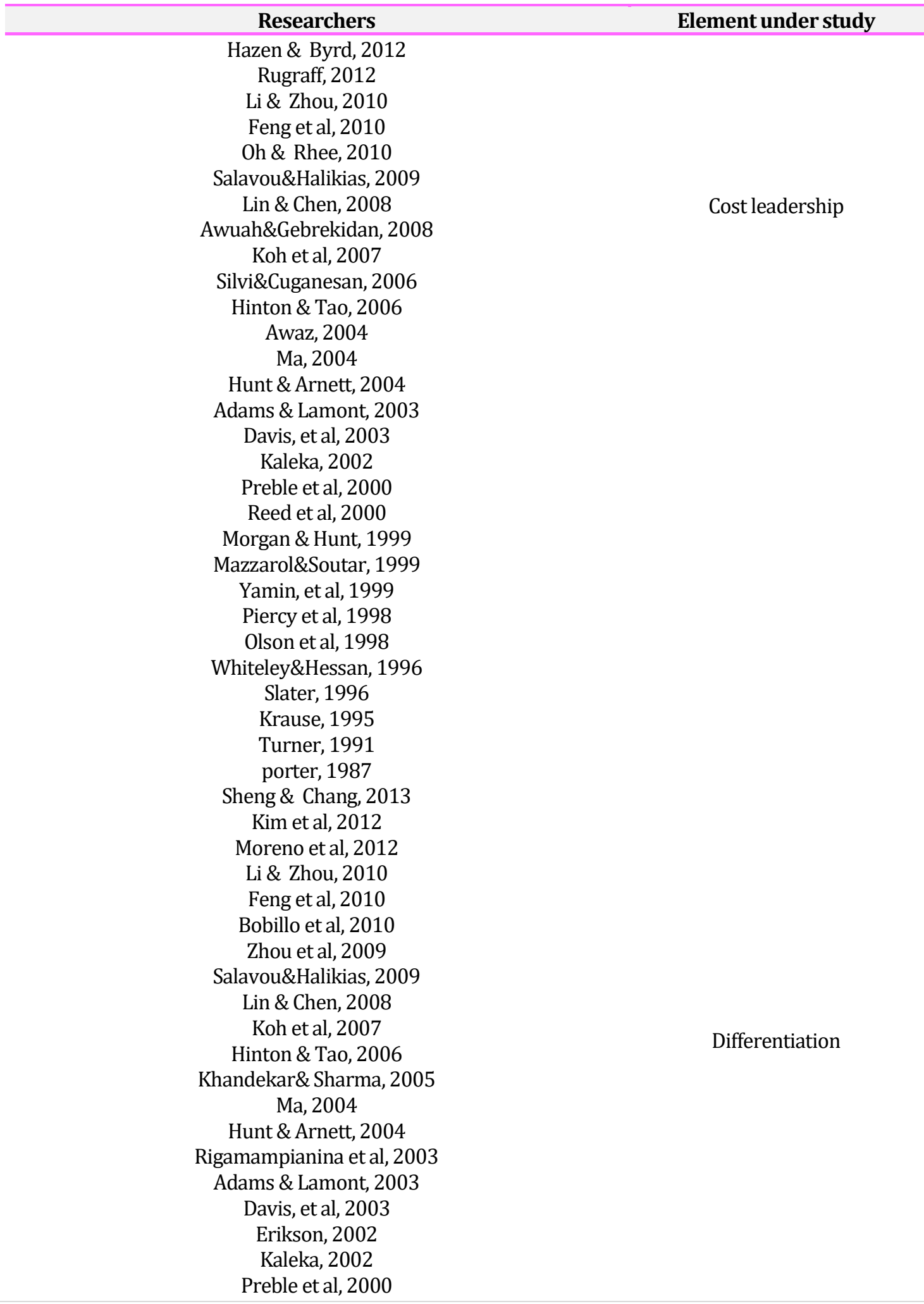


Reed et al, 2000

Morgan \& Hunt, 1999

Mazzarol\&Soutar, 1999

Yamin, et al, 1999

Piercy et al, 1998

Olson et al, 1998

Whitehill, 1997

Whiteley\&Hessan, 1996

Slater, 1996

Long \& Koch, 1995

Turner, 1991

porter, 1987

Lew \&Sinkovics, 2013

Li \& Zhou, 2010

Feng et al, 2010

Salavou\&Halikias, 2009

Swink\& Song, 2007

Koh et al, 2007

Weerawardena\&0'Cass, 2004

Ma, 2004

Hunt \& Arnett, 2004

Kaleka, 2002

Mazzarol\&Soutar, 1999

Yamin, et al, 1999

Piercy et al, 1998

Olson et al, 1998

Slater, 1996

Turner, 1991

porter, 1987

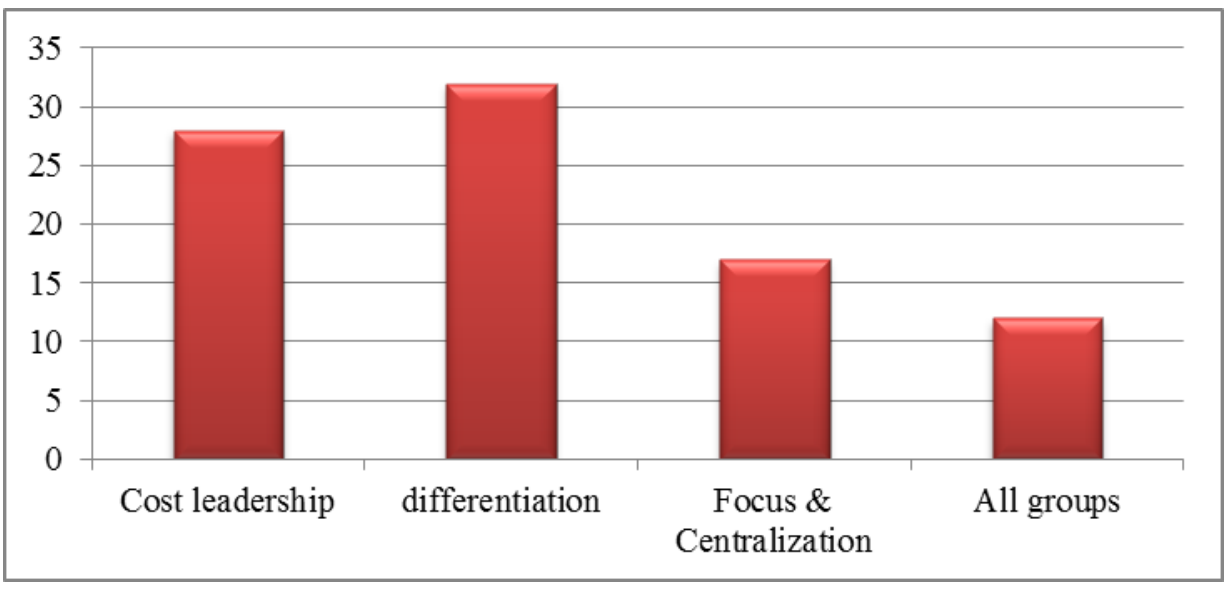

Figure 2. The aspects under study in previous studies

\section{Discussion and Conclusion}

Through field analysis, creditable articles on competitive advantages and the aspects indexed in Emerald and Science Direct were examined in detail. The purpose of the survey
Centralization

Centralization

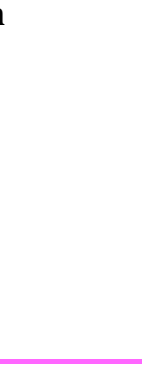


strategies), among which differentiation strategy has been most used in other works and a minimum number of studies dealt with the three strategies at the same time. Moreover, the results showed that survey of competitive advantages in the fields of marketing strategic management, strategic management, marketing management, IT, knowledge management, entrepreneurship, and theory were based on resources and HR management. Furthermore, maximum and minimum frequencies in the studies were for strategic management and entrepreneurship. The results of this work may be helpful for studies on competitive studies, the aspects, and measurement at business level.

\section{Reference}

Awazu, Y. (2004). Informal network players, Knowledge integration, and competitive advantage, Journal of knowledge management, 8(3): 62-70.

Awuah, B., \& Gebrekidan, D. (2008). Networked (interactive) position: a new view of developing and sustaining competitive advantage, Competitiveness Review: An International Business Journal, 18(4): 333350.

Bobillo, A.; Iturriaga, F., \&Gaite, T. (2010). Firm performance and international diversification: The internal andexternal competitive advantages, International Business Review, 19: 607-618.

Castro, G.; Lopez, J.; Saez, P., \& Salazar, A. (2006). Organizational capital as competitive advantage of the firm, Journal of Intellectual Capital, 7(3): 324-337.

Chuang, S. (2004). A resource-based perspective on knowledge management capability and competitive advantage: an empirical investigation, Expert Systems with Applications, 27: 459-465.
Davis, L.; Dehning, B., \&Stratopoulos, T. (2003). Does the market recognize ITenabled competitive advantage?, Information \& Management, 40: 705-716.

Erikson, T. (2002). Entrepreneurial capital: the emerging venture's most important asset and competitive advantage, Journal of Business Venturing, 17: 275-290.

Fahy, J. (2002). A resource-based analysis of sustainable competitive advantage in a global environment, International Business Review, 11: 57-78.

Feng, T.; Sun, L., \& Zhang, Y. (2010). The effects of customer and supplier involvement on competitive advantage: An empirical study in China, Industrial Marketing Management, 39: 1384-1394.

Fudson, Z. \& Radnor, Z. (2003). The effect of regulatory practices in achieving competitive advantage, Work Study, 51(7): 346-356.

Ghingold, M., \& Johnson, B. (1998).Intrafirm technical knowledge and competitive advantage: a framework for superior market driven performance, Journal of Business \& Industrial Marketing, 13(1): 70-81.

Hazen, B., \& Byrd, T. (2012). Toward creating competitive advantage with logistics information technology, International Journal of Physical, Distribution \& Logistics Management, 42(1): 8-35.

Hill, C. W. L., \& Jones, G. R. (1998). Strategic Management Theory, Houghton Mifflin Com, 2st ed, USA: 105-127.

Hinton, C. \& Tao, Y., (2006). Exploring sources of competitive advantage E-business applications within the Chinese real estate industry, Journal of Technology Management in China, 1(1): 92-106.

Hunt, S., \& Arnett, D. (2004). Market Segmentation Strategy, Competitive 
Advantage, and Public Policy: Grounding Segmentation Strategy in ResourceAdvantage Theory, Australasian Marketing Journal, 12(1): 7-25.

Jüttner, U., \&Wehrli, P. (1994). Competitive Advantage Merging Marketing and the Competence-based Perspective, Journal of Business \& Industrial Marketing, 9(4): 42-53.

Kaleka, A. (2002). Resources and capabilities driving competitive advantage in export markets: guidelines for industrial exporters, Industrial Marketing Management, 31: 273283.

Kearns, G., \& Lederer, A. (2000). The effect of strategic alignment on the use of IS-based resources for competitive advantage, Journal of Strategic Systems, 9: 265-293.

Kearns, G., \& Lederer, A. (2004). The impact of industry contextual factors on IT focus and the use of IT for competitive advantage, Information \& Management, 41: 899-919

Khandekar, A., \& Sharma, A. (2005). Managing human resource capabilities for sustainable competitive advantage an empirical analysis from Indian global organizations, Education + Training, 47(8/9): 628-639.

Kim, K.; Jeon, B.; Jung, H.; Lu, V., \& Jones, J. (2012).Effective employment brand equity through sustainable competitive advantage, marketing strategy, and corporate image, Journal of Business Research, 65: 1612-1617.

Koh, S.; Simpson, M., \& Padmore, J. (2007). Could e-business create a competitive advantage in UK SMEs?, Benchmarking: An International Journal, 14(3): 320-351.

Krause, C. (1995). Japanese microelectronics: Creating competitive advantage by vertical interaction, Journal of Economic Behavior and Organization, 28: 49-61.
Lew, Y., \&Sinkovics, R. (2013). Crossing Borders and Industry Sectors: Behavioral Governance in Strategic Alliances and Product Innovation for Competitive Advantage, Long Range Planning, 46: 13-38.

Li, J., \& Zhou, K. (2010). How foreign fi rms achieve competitive advantage in the Chinese emerging economy: Managerial ties and market orientation, Journal of Business Research, 6: 856-862.

Liao, S., \&Chien Hu, T. (2007). Knowledge transfer and competitive advantage on environmental uncertainty: An empirical study of the Taiwan semiconductor industry, Technovation, 27: 402-411.

Lim, J.; Stratopoulos, T., \& Wirjanto, T. (2012). Role of IT executives in the firm's ability to achieve competitive advantage through IT capability, International Journal of Accounting Information Systems, 13: 21-40.

Lin, M., \& Chen, C. (2008). Integration and knowledge sharing: transforming to longterm competitive advantage, International Journal of Organizational Analysis, 16(1/2): 83-108.

Long, C., \& Koch, M. (1995). Using Core Capabilities to Create Competitive Advantage, Available at: http://www.accessmylibrary.com/article1G1-17353701/using-core-capabilitiescreate.html

Ma, H. (2004). Toward global competitive advantage, Management Decision, 42(7): 907-924.

Massa, S., \&Testa, S. (2009). A knowledge management approach to organizational competitive advantage: Evidence from the food sector, European Management Journal, 27: $129-141$.

Mazzarol, T., \&Soutar, G. (1999). Sustainable competitive advantage for educational 238 | Page 
institutions: a suggested model, The International Journal of Educational Management, 13(6): 287-300.

Moreno, E.; Lorente, J., \& Rio, J. (2012). Environmental human resource management and competitive advantage, Management Research: The Journal of the Ibero-american Academy of Management, 10(2): 125-142.

Morgan, R., \& Hunt, S. (1999). RelationshipBased Competitive Advantage: The Role of Relationship Marketing in Marketing Strategy, Journal of Business Research, 46: 281-290.

Oh, J., \& Rhee, S. (2010). Influences of supplier capabilities and collaboration in new car development on competitive advantage of carmakers, Management Decision, 48(5): 756-774.

Olson, E; Cooper, R \& Slater, S. (1998).Design Strategy and Competitive Advantage, Business Horizons, 55-61.

Piercy, N; Kaleka, A \& Katsikeas, C. (1998). Sources of Competitive Advantage in High performing Exporting Companies, Journal of World Business, 33: 378-393.

Porter, M. (1987). From Competitive Advantage to Corporate Strategy. Harvard Business Review May-June (3): 43-59.

Porter, M. E. (1980). Competitive Strategy, Techniques for Analyzing Industries and Competitors, Simon \& Schuster Inc, 1-422.

Porter, M. E. (1997)." How Competitive Forces Shape Strategy", Harvard Business Review, 57(2): 137-145.

Preble, J; Reichel, A. \& Hoffman, R. (2000). Strategic alliances for competitive advantage: evidence from Israel's hospitality and tourism industry, Hospitality Management, 19: 327-341.
Reed, R; Lemak, D. \& Mero, N. (2000). Total quality management and sustainable competitive advantage, Journal of Quality Management, 5: 5- 26.

Rijamampianina, R; Abratt, R. \& February, Y. (2003). A Framework for concentric diversification through sustainable competitive advantage, Journal of Management Decision, 41(2): 362-371.

Rugraff, E. (2012). The new competitive advantage of automobile manufacturers, Journal of Strategy and Management, 5(4): 407-419.

Salavou, H. \&Halikias, J. (2009). Strategy types of exporting firms: a view on the basis of competitive advantage, European Business Review, 21(2): 144 - 158.

Sheng, M. \& Chang, S. (2013). Knowledge barriers, knowledge transfer, and innovation competitive advantage in healthcare settings, Management Decision, 51(3): 461-478.

Silvi, R. \&Cuganesan, S. (2006). Investigating the management of knowledge for competitive advantage A strategic cost management perspective, Journal of Intellectual Capital, 7(3): 309-323.

Slater, S. (1996). The Challenge of Sustaining Competitive Advantage, Industrial Marketing Management, 25: 79-86.

Swink, M. \& Song, M. (2007).Effects of marketing-manufacturing integration on new product development time and competitive advantage, Journal of Operations Management, 25: 203-217.

Tan, H. (2009). Firm-employee relationship strength - Competitive advantage through people revisited: A commentary essay, Journal of Business Research, 62: 1108-1109.

Toppinen, A; Toivonen, R. \&Tatti, N. (2007). Sources of competitive advantage in 
woodworking firms of Northwest Russia, International Journal of Emerging Markets, 2(4): 383-394.

Turner, P. (1991). Using Information to Enhance Competitive Advantage the Marketing Options, European Journal of Marketing, 25(6): 55-64.

Walters, D; Halliday, M. \& Glaser, S. (2002).Added value, enterprice value and competitive advantage, Journal of management Decision, 40(9): 823-833.

Weerawardena, J. \& O'Cass, A. (2004). Exploring the characteristics of the marketdriven firms and antecedents to sustained competitive advantage, Industrial Marketing Management, 33: 419- 428.

Whitehill, M. (1997). Knowledge-based Strategy to Deliver Sustained Competitive Advantage, Long Range Planning, 30(4): 621627.

How to cite this article: Manijeh Gareche, Seyed Mahmoud Hosseini, Masoud Taheri, A Comprehensive Literature Review in Competitive Advantages of Businesses. International Journal of Advanced Studies in Humanities and Social Science, 2019, 8(3), 223-240. http://www.ijashss.com/article_84369.html
Whiteley, R. \& Hessan, D. (1996). Customercentred growth: five strategies for building competitive advantage, Managing Service Quality, 6(5): 47-52.

Yamin, S; Gunasekaran, A. \& Mavondo, F. (1999). Relationship between generic strategies, competitive advantage and organizational performance: an empirical analysis, Technovation, 19: 507-518.

Zhang, M. \& Lado, A. (2001). Information systems and competitive advantage: a competency- based view, Technovation, 21: 147-156.

Zhou, K; Brown, J. \& Dev, C. (2009). Market orientation, competitive advantage, and performance: A demand-based perspective, Journal of Business Research, 62: 1063-1070. 